\title{
Pengaruh Pola Asuh Terhadap Percaya Diri dan Prestasi Belajar Anak Desmigratif (Desa Migra Inovatif) Pati
}

\author{
(Parenting Effects on Innovative Migrant Village Children's Accademic \\ Achievement and Confidence in Pati) \\ Richma Hidayati ${ }^{1,2}$, Nur Hidayah'1, M. Ramli' ${ }^{1}$, IM. Hambali' ${ }^{1}$, S. Santoso ${ }^{2}$ \\ ${ }^{1}$ Universitas Negeri Malang, Jl. Semarang No. 5 Malang, Jawa Timur, Indonesia \\ ${ }^{2}$ Universitas Muria Kudus, Gondangmanis Bae, PO Box 53, Kudus, Jawa Tengah, Indonesia \\ *Penulis korespondensi, Surel: richma.hidayati@umk.ac.id
}

Paper received: 27th-Jan-2021; revised: 10th-Mar-2021; accepted: 10th-Mar-2021

\begin{abstract}
This study investigates the empirical findings on the parenting effects on innovative migrant village children's confidence and academic achievement in Pati. This quasi-experimental research uses a non-equivalent control group design with a $2 \times 2$ factorial version. Its subjects were 75 children of Indonesian Migrant workers. The test and non-test data were obtained and analyzed using Manova statistics. Generally, the research results confirm that parenting carries substantial effects on children's confidence and academic achievement.
\end{abstract}

Keywords: parenting; confidence; academic achievement; innovative migrant village

\begin{abstract}
Abstrak
Penelitian ini bertujuan untuk mengkaji temuan empirik tentang pengaruh pola asuh terhadap percaya diri dan prestasi belajar anak desmigratif (Desa Migra Inovatif) Pati. Penelitian eksperimen semu ini menggunakan desain non-equivalent control group versi faktorial $2 \times 2$. Subjek penelitian melibatkan 75 anak Tenaga Kerja Indonesia (TKI) dan Tenaga Kerja Wanita (TKW). Data diperoleh dengan tes dan non-tes, kemudian dianalisis dengan teknik statistik Manova. Secara garis besar, hasil penelitian menunjukkan bahwa pola asuh memiliki pengaruh yang signifikan terhadap percaya diri dan prestasi belajar anak.
\end{abstract}

Kata kunci: pola asuh; percaya diri; prestasi belajar; desa migra inovatif

\section{Pendahuluan}

Indonesia adalah negara yang menyalurkan tenaga kerja ke negara-negara lain dengan jumlah yang cukup banyak. Badan Nasional Penempatan dan Perlindungan Tenaga Kerja Indonesia (BNP2TKI) tahun 2018 menjelaskan terdapat 204.836 tenaga kerja yang telah disalurkan untuk menjadi Tenaga Kerja Indonesia (TKI). Sebanyak 51\% TKI ditempatkan pada sektor informal dan sebanyak 69\% dari jumlah TKI adalah tenaga kerja wanita (Subadi, 2010). Sementara itu, 39\% dari total TKI berstatus belum kawin. Artinya, sebagian besar tenaga kerja tersebut adalah orangtua dengan status sudah menikah atau bercerai.

Banyaknya jumlah TKI dan TKW yang menyebar di seluruh Indonesia membuat pemerintah mencanangkan program Desmigratif (Desa Migra Inovatif dan Produktif). Seperti halnya di Desa Kayen Pati, terdapat program desmigratif yang merupakan salah satu desa dengan tingkat pekerjaan sebagai TKW maupun TKI yang sangat tinggi. Dengan bantuan dari pemerintah desa dan Bank Negara Indonesia terbentuklah Desmigratif (Desa Migra Inovatiif dan Produktif). Desmigratif tidak hanya menyasar pada warga desa supaya bisa mandiri dan 
memiliki usaha mandiri namun juga kepada anak-anak yang ditinggalkan oleh orangtuanya yang menjadi TKW maupun TKI. Munculnya banyak permasalahan yang terjadi pada anakanak yang ditinggalkan karena para TKI dan TKW ini lebih memilih bekerja di luar negeri dan tugas utama dalam mendidik anak pun terabaikan.

Pada Undang-Undang Nomor 23 Tahun 2012 pasal 26 ayat 1 tertulis bahwa kewajiban orangtua terhadap anak adalah mengasuh, memelihara, mendidik, dan melindungi anak, menumbuhkembangkan anak sesuai dengan kemampuan, bakat, dan minatnya, serta mencegah terjadinya perkawinan pada usia anak-anak. Ketika salah satu dari orangtua memutuskan untuk bekerja di luar negeri, maka kewajiban tidak dapat dipenuhi secara maksimal. Anak-anak mereka menjadi kehilangan hak untuk diasuh dan mendapat perlindungan. Akibatnya, peran utama orangtua tersebut digantikan oleh orangtua asuh atau wali. Namun, peran tersebut tidak dapat digantikan secara penuh oleh orangtua asuh. Anakanak yang seharusnya didampingi oleh ayah dan ibu mereka harus kehilangan sosok pendamping untuk sementara waktu sehingga anak pekerja migran menjadi pihak yang rentan (Syamsudin, 2017). Mengingat TKI belum mendapatkan perhatian lebih untuk mendapatkan jaminan sosial, anak pekerja migran sering kali ditempatkan pada kualitas hidup yang minimal.

Sebuah penelitian menunjukkan bahwa sebanyak 40\% anak TKI memiliki perkembangan psikososial yang kurang baik, seperti prestasi anak mengalami penurunan atau perkembangan yang tidak jauh meningkat, tidak memiliki banyak teman dan/atau teman akrab, dan lain sebagainya (Suharto \& Nurwati, 2018). Permasalahan lain yang dialami oleh anak-anak TKI dan TKW adalah kepercayaan diri. Tidak adanya rasa percaya diri membuat diri anak cenderung pesimis (Selmi, Rebai, Chtara, Naceur, \& Sahli, 2018), merasa rendah diri bila ada di antara teman-temannya (Tymes, Outlaw, \& Hamilton, 2016), anak menganggap dirinya tidak berguna (Cook, Snow, Binns, \& Cook, 2015), tidak bisa melakukan hal yang baik karena selalu ragu apabila ingin melakukan sesuatu (Franz, Cailor, Chen, Thornton, \& Norfolk, 2020; Gurler, 2015; Rezaei, 2012), anak selalu merasa gelisah terhadap respon yang diterima atas tindakan yang telah dilakukan. Tumbuh kembang anak menjadi terhambat dan kurang optimal, dengan kata lain anak tersebut menjadi pribadi yang lemah.

Permasalahan mengenai percaya diri anak Desmigratif sering terjadi di lingkungan sekolah khususnya pada saat anak diperintahkan untuk maju dan berbicara di depan kelas. Tidak sedikit dari mereka yang merasa takut, gugup, dan bingung saat berada di depan kelas (Siregar \& Asih, 2017), atau bahkan mereka merasa sangat malu apabila dilihat oleh temanteman sekelasnya (Campos, Zagalaz, \& Granados, 2015). Tidak hanya itu, permasalahan kepercayaan diri anak yang rendah juga menghambat perkembangan potensi yang dimiliki, mematikan kreativitas yang ada dalam diri anak (Oney \& Oksuzoglu-Guven, 2015), atau bahkan dapat menumpulkan bakat yang dimilikinya (Reinhardt, 1955). Sebaliknya bila anak memiliki kepercayaan diri yang tinggi tentu hal ini sangat membantu dirinya untuk lebih berprestasi (Tymes et al., 2016) dalam segala hal dan memudahkan anak untuk mencapai kesuksesan di masa depan.

Hasil wawancara dengan pengurus Desmigratif Desa Kayen juga mendapati hal yang sama. Anak-anak yang salah satu atau kedua orangtuanya bekerja di luar negeri dan hanya diasuh oleh kakek atau nenek bahkan ada pula yang dititipkan kepada paman atau bibi yang ada di dekat rumah memiliki permasalahan percaya diri dan prestasi belajar yang rendah. Berdasarkan hasil observasi di Desa Kayen, ditemui anak-anak yang ditinggalkan oleh orang 
tuanya memiliki permasalahan dalam percaya diri dan prestasi belajarnya di sekolah yang disebabkan oleh perbedaan pola asuh di mana anak-anak TKI dan TKW tidak dididik dan diasuh langsung oleh orangtuanya. Hal ini akan berbeda pula bagi anak yang kedua orangtuanya bekerja di luar negeri dan anak diasuh oleh nenek maupun kakeknya (Azkeskin, Güven, Güral, \& Sezer, 2013). Peran orangtua dalam mendidik anak sama sekali hilang (Hakim \& Supriyadi, 2012). Nenek dan kakek dalam mengasuh cucu mereka akan mengutamakan kebahagiaan sang cucu tapi sering tanpa batas yang muncul adalah terlampaui menyayangi dan terlalu menuruti semua kemauan cucunya tanpa melihat dan mempertimbangkan efek baik dan buruk (Irani \& Laksana, 2018; Sultana \& Fatima, 2017). Pola asuh ini akan berdampak pada anak yang tidak diasuh langsung oleh orangtuanya.

Tanpa pengasuhan langsung dari orangtua, akan muncul hambatan pada psikososial, percaya diri, karakter dan juga psikologis anak yang akan mengganggu perkembangan selanjutnya. Anak-anak yang ditinggalkan oleh orangtuanya akan memiliki kepercayaan diri yang jauh berbeda dengan anak-anak normal biasanya yang diasuh penuh oleh kedua orangtuanya (Syamsudin, 2017). Anak-anak yang ditinggalkan oleh ibunya yang menjadi seorang TKW di negara lain dan bertahun-tahun tidak pulang hanya diasuh dan dididik oleh sang ayah. Anak kurang mengenal kasih sayang, karena itu kecenderungan anak menjadi mudah untuk mencari perhatian di luar bahkan di sekolah dengan berbagai macam tingkah lakunya bisa menjadi permasalahan yang besar. Sang ayah dalam mendidik akan memunculkan dua hal besar dalam diri anak, pertama ayah mengajarkan kemandirian utuh kepada sang anak yang akan membentuk karakter positif kemandirian yang kuat pada anak, kedua ayah akan mendidik dengan penuh kecemasan dan terlalu overprotective karena sang ayah mengira bisa memegang dua peran sebagai ibu dan ayah sekaligus dan akan membentuk karakter anak yang kurang percaya diri dan selalu diliputi oleh ketakutan ketika akan melakukan sesuatu. Keutuhan pembinaan dan pola asuh dari kedua orangtua akan tumpang tindih dan sering kali menjadikan anak memiliki salah persepsi tentang tugas dan tanggung jawab orang tua. Pada dasarnya anak akan belajar akan kasih sayang dari sang ibu dan belajar akan kuatnya mental dan kemandirian dari sang ayah. Oleh karenanya, penelitian ini bertujuan untuk menguji secara empirik tentang pengaruh pola asuh terhadap percaya diri dan prestasi belajar anak desmigratif (Desa Migra Inovatif) Pati.

\section{Metode}

Penelitian ini merupakan jenis penelitian eksperimen semu dengan menggunakan desain non-equivalent control group versi faktorial $2 \times 2$. Subjek penelitian ditentukan dengan cara acak kelompok (intact-group). Subjek penelitian adalah 75 anak TKI dan TKW di Desmigratif Kayen Pati yang menjadi kelompok eksperimen sekaligus kelompok kontrol. Metode yang digunakan dalam penelitian ini adalah Quasi Eksperimen dengan desain nonequivalent control group. Instrumen penelitian yang digunakan adalah Skala Pola Asuh (demokratis, permisif dan otoriter), Skala Percaya Diri (dengan indikator: yakin akan kemampuan diri sendiri, optimis, objektif, tanggung jawab dan berfikir rasional) dan Skala Prestasi Belajar (berdasarkan indikator kognitif, afektif dan psikomotor). Analisis data yang digunakan adalah Manova. Manova merupakan salah satu analisis multivariate dan juga merupakan perluasan dari univariat yang dapat digunakan untuk memerikasa secara stimultan hubungan antara beberapa variabel bebas dengan skala pengukuran nominal atau ordinal dan dinyatakan sebagai perlakuan dengan dua atau lebih variabel tak bebas yang mempunyai skala pengukuran interval atau rasio dan dinyatakan sebagai variabel dependen. 
$\mathrm{X} \quad$ : Pola Asuh Orangtua yang terdiri dari :

X1 : Demokratis

X2 : Otoriter

X3 : Permisif

Y1 : Percaya Diri

Y2 : Prestasi Belajar

Untuk menguji hipotesis, diperlukan uji prasyarat analisis, yaitu: (1) uji normalitas, bertujuan untuk mengetahui apakah data berdistribusi normal atau tidak, (2) uji homogenitas, bertujuan untuk mengetahui apakah subjek penelitian berasal dari populasi yang memiliki variansi homogen atau tidak. Jika uji prasyarat analisis terpenuhi, maka pengujian hipotesis dengan analisis Manova dapat dilanjutkan dengan menggunakan bantuan aplikasi SPSS 17. Taraf signifikansi yang ditetapkan adalah $\alpha=0,05$, sedangkan prosedur pengambilan keputusan yaitu dengan melihat besarnya nilai $\mathrm{p}$ atau sig. Jika nilai sig. $<\alpha$, maka $\mathrm{H}_{0}$ ditolak, dan jika nilai sig. $>\alpha$, maka $\mathrm{H}_{0}$ gagal ditolak.

\section{Hasil dan Pembahasan}

\subsection{Hasil}

Hasil uji prasyarat analisis berupa uji normalitas dan uji homogenitas terhadap variabel hasil belajar ditunjukkan pada Tabel 1 dan Tabel 2. Berdasarkan Tabel 1, diketahui nilai sig. untuk masing-masing data lebih besar dari 0,05. Oleh karena nilai sig. $>0.05$, maka dapat disimpulkan bahwa semua data berdistribusi normal. Berdasarkan Tabel 2, diketahui nilai sig. dari Levene's Test of Equality data hasil belajar pengetahuan, keterampilan, dan sikap lebih besar dari 0,05. Dikarenakan nilai sig. > 0,05 maka dapat disimpulkan bahwa varian dari masing-masing kelompok adalah homogen.

Tabel 1. Hasil Uji Normalitas

\begin{tabular}{llcc}
\hline & & Percaya Diri & Prestasi Belajar \\
\hline $\mathrm{N}$ & & 80 & 80 \\
Normal Parameters, & Mean & 59,09 & 106,33 \\
& Std. Deviation & 5,829 & 7,663 \\
Most Extreme Differences & Absolute & 0,098 & 0,094 \\
& Positive & 0,071 & 0,094 \\
& Negative & $-0,098$ & $-0,062$ \\
Kolmogorov-Smirnov Z & & 0,878 & 0,840 \\
Asymp. Sig. (2-tailed) & & 0,624 & 0,680 \\
\hline
\end{tabular}


Tabel 2. Hasil Uji Homogenitas

\begin{tabular}{lcccccc}
\hline Pola Asuh & F & Df1 & Df2 & sig & Keterangan & Pola Asuh \\
\hline Demokratis & 2,586 & 3 & 75 & 0,65 & Homogen & Demokratis \\
Otoriter & 2,746 & 3 & 75 & 0,061 & Homogen & Otoriter \\
Permisif & 1,433 & 3 & 75 & 0,265 & Homogen & Permisif \\
\hline
\end{tabular}

Hasil uji prasyarat analisis menunjukkan bahwa data berdistribusi normal dan variansi antar kelompok homogen, maka pengujian hipotesis dengan analisis Manova dapat dilanjutkan. Berdasarkan tabel Tests of Between-Subjects Effects pada analisis Manova, hasil pengujian sembilan hipotesis penelitian diringkas pada Tabel 3 .

Tabel 3. Hasil Uji Hipotesis

\begin{tabular}{clccl}
\hline Source & Dependent Variable & F & Sig. & Keterangan (Ho) \\
\hline TRM & Demokratis & 4,941 & 0,046 & Gagal ditolak \\
& Permisif & 0,263 & 0,665 & Gagal ditolak \\
& Otoriter & 1,278 & 0,289 & Ditolak \\
KA & Demokratis & 9,390 & 0,005 & Gagal ditolak \\
& Permisif & 7,976 & 0,007 & Ditolak \\
& Otoriter & 0,566 & 0,476 & Gagal ditolak \\
TRM $*$ KA & Demokratis & 4,343 & 0,090 & Ditolak \\
& Permisif & 0,089 & 0,681 & Gagal ditolak \\
& Otoriter & $1 ., 23$ & 0,472 & Gagal ditolak \\
\hline
\end{tabular}

\subsection{Pembahasan}

Berdasarkan hasil penelitian, anak yang orangtuanya menerapkan pola asuh otoriter akan cenderung memiliki tingkat percaya diri dan prestasi belajar yang rendah. Orangtua memaksa anak untuk mematuhi peraturan dan menghukum mereka secara tegas jika melanggarnya (Perilaku et al., 2013). Mereka lebih mengambil jarak dan kurang hangat dibanding dengan orangtua yang lain. Akibatnya, anak cenderung menjadi lebih tidak puas dan menarik diri (Haryono, 2015). Orangtua hanya mengutamakan pendapat dan pemikirannya yang dianggap paling benar dan tidak memberikan kesempatan pada keinginan anak.

Hal tersebut akan membuat anak merasa takut kepada orangtuanya ataupun lingkungan sosialnya, merasa kurang percaya diri dan prestasi belajar dan kurang berani dalam berpendapat. Selanjutnya, anak yang orangtuanya menerapkan pola asuh demokratis akan menjadikan anak memiliki tingkat percaya diri dan prestasi belajar cenderung tinggi. Orangtua dengan gaya demokratis mendorong anak untuk bebas tetapi tetap memberikan batasan dan mengendalikan tindakan dari mereka (Jongerden \& Bögels, 2015). Pada pola asuh demokratis memiliki lebih banyak interaksi antara orangtua dan anak, dimana orangtua akan sering mengajak anak melakukan diskusi dan memberi pemahaman yang disertai dengan adanya rasa tanggung jawab terhadap suatu hal dapat memberikan pengaruh yang lebih positif terhadap percaya diri dan prestasi belajar anak. Serta dapat membantu dalam mengembangkan pemahaman anak tentang pentingnya memiliki kepercayaan diri dan prestasi belajar dalam dirinya (Cimermanová, 2018).

Pola asuh demokratis juga memiliki bentuk perhatian yang lebih banyak dibandingkan dengan pola asuh otoriter dan permisif. Dalam hal ini membuat anak merasa bahwa mereka 
memiliki orangtua yang dapat berperan sebagai orang yang paling mereka percayai, sehingga anak mampu mengendalikan diri dan berani berpendapat serta memberikan keputusan yang tepat. Kemudian orangtua yang menerapkan pola asuh permisif akan membuat anak memiliki tingkat percaya diri dan prestasi belajar yang sedang. Pada pola asuh ini, orangtua kurang atau bahkan sama sekali tidak mempedulikan perkembangan psikis anak. Anak dibiarkan berkembang sendiri, dan juga orangtua lebih mementingkan kepentingannya sendiri daripada kepentingan anak-anaknya. Perkembangan kepribadian anak menjadi terabaikan, banyak orangtua yang terlalu sibuk dengan kegiatannya sendiri dengan berbagai macam alasan. Orangtua yang menerapkan pola asuh permisif, akan lebih banyak membiarkan anak melakukan apapun tanpa adanya pengawasan sehingga hal tersebut dapat membuat anak cenderung lebih banyak berinteraksi dengan lingkungan pertemanannya, dan mengakibatkan seseorang memiliki rasa percaya diri dan prestasi belajar yang rendah dalam dirinya, sehingga komunikasi dengan keluarganya kurang terjalin (Sofyan, 2019).

Berdasarkan penjelasan pada paragraf sebelumnya, pola asuh memiliki peranan yang sangat penting terhadap kepercayaan diri dan prestasi belajar anak. Perkembangan kepercayaan diri pada masa remaja dipengaruhi oleh beberapa faktor diantaranya adalah pola asuh, kematangan usia, jenis kelamin, penampilan fisik, hubungan keluarga, teman sebaya (House \& Raja, 2019; Pettersson, 2018).

Orangtua yang menerapkan pola asuh otoriter, menjadikan anak memiliki percaya diri dan prestasi belajar yang rendah, sedangkan orangtua yang menerapkan pola asuh demokratis maka akan menjadikan anak tersebut memiliki kepercayaan diri yang tinggi, selanjutnya orangtua yang menerapkan pola asuh permisif akan menjadikan anak memiliki percaya diri dan prestasi belajar yang sedang. Hal ini menunjukkan bahwa pola asuh yang demokratis sebaiknya diterapkan oleh orangtua untuk anak-anaknya karena akan menjadikan anak memiliki percaya diri dan prestasi belajar yang tinggi (Komara, 2016), berani mengemukakan pendapat dan berani bertanya.

Pola asuh orangtua mempengaruhi tumbuhnya kepercayaan diri dan prestasi belajar pada diri anak desmigratif. Semakin baik pola asuh orangtua yang diterapkan maka akan semakin tinggi tingkat kepercayaan diri dan prestasi belajar padapada anak, begitu sebaliknya semakin jelek pola asuh orangtua maka akan semakin rendah tingkat kepercayaan diri pada diri seseorang. Pola asuh orangtua sangat erat hubungannya dengan rasa percaya diri dan prestasi belajar anak. Individu yang memiliki pola asuh orangtua yang baik maka ia akan sanggup untuk menumbuhkan percaya diri dan prestasi belajar dalam dirinya dengan baik pula (Asiyah, Walid, \& Kusumah, 2019).

\section{Simpulan}

Berdasarkan temuan penelitian ini, dapat disimpulkan bahwa pola asuh orangtua baik pola asuh demokratis, pola asuh otoriter dan pola asuh permisif, berpengaruh secara signifikan terhadap percaya diri dan prestasi belajar anak TKI dan TKW di Desmigratif Pati. Meskipun baru tahap awal, penelitian ini sangat penting untuk dilakukan karena banyaknya penduduk Indonesia yang menjadi TKI dan TKW yang menyebabkan banyak anak yang ditinggalkan dan diasuh oleh kakek, nenek atau walinya. Pola asuh yang berbeda inilah sering memunculkan permasalahan dalam fisik, psikis, sosial, percaya diri, prestasi belajar dan psikososial. Selain itu sering kali yang menjadi fokus utama dalam penelitian di desmigratif adalah permasahan UMKM dan ekonominya namun soal parenting, anak dan hubungan 
diantara keduanya sering diabaikan. Oleh karena itulah penelitian ini menjadi urgent. Penelitian ini akan memberikan pemahaman akan pentingnya pola asuh yang dilakukan wali kepada anak-anak TKI dan TKW sehingga memberikan dampak terhadap kepercayaan diri dan prestasi belajarnya. Anak-anak pun akan memahami pentingnya memiliki kepercayaan diri dan prestasi belajar yang bagus bagi masa depan yang akan datang. Dari sinilah akan menjadi awal hubungan dan pola asuh yang tepat antara wali dan anak-anak TKI dan TKW di desmigratif. Bagi pendidik juga penelitian ini dapat membantu untuk lebih memahami kondisi dan situasi siswa yang diampunya, prestasi belajar yang belum maksimal bisa disebabkan oleh pola asuh dan rendahnya kepercayaan diri juga dipengaruhi oleh pola asuh dari orangtua atau walinya. Oleh karena itu, pendidik harus mampu untuk melihat akar permasalahan utama yang terjadi pada siswa sehingga bisa memberikan penanganan yang tepat. Temuan penelitian ini penting sebagai dasar bagi konselor dalam merancang program BK, khususnya layanan bagi siswa dengan background orangtua migran

\section{Daftar Rujukan}

Asiyah, A., Walid, A., \& Kusumah, R. G. T. (2019). Pengaruh Rasa Percaya Diri Terhadap Motivasi Berprestasi Siswa pada Mata Pelajaran IPA. Scholaria: Jurnal Pendidikan Dan Kebudayaan, 9(3), 217-226.

Azkeskin, K., Güven, G., Güral, M., \& Sezer, T. (2013). Parenting styles: Parents with 5-6 year old children. Journal of Educational and Instructional Studies in the World, 3(1), 74-82.

Campos, G. G., Zagalaz, J. C., \& Granados, S. R. (2015). Correlational study of psychological variables selfconfidence and anxiety. Motriz: Revista de Educação Física, 21(4), 352-360.

Cimermanová, I. (2018). The effect of learning styles on academic achievement in different forms of teaching. International Journal of Instruction, 11(3), 219-232. https://doi.org/10.12973/iji.2018.11316a

Cook, A. L., Snow, E. T., Binns, H., \& Cook, P. S. (2015). Self-reported student confidence in troubleshooting ability increases after completion of an inquiry-based PCR practical. Biochemistry and Molecular Biology Education, 43(5), 316-323.

Franz, T., Cailor, S., Chen, A. M. H., Thornton, P., \& Norfolk, M. (2020). Improvement of student confidence and competence through a self-care skills multi-course integration. Currents in Pharmacy Teaching and Learning, 12(4), 378-387.

Gurler, I. (2015). Correlation between self-confidence and speaking skill of English language teaching and English language and literature preparatory students. Curr Res Soc Sci, 1(2), 14-19.

Hakim, M. A., \& Supriyadi, Y. K. W. (2012). The contents of Indonesia child-parent attachment: Indigenous and cultural analysis. International Society for the Study of Behavioural Development Bulletin, 2(62), 11-15.

Haryono. (2015). Learning Achievement Improvement Efforts Course Learn and Learning Using the Jigsaw Method and Card Media in STKIP PGRI Ngawi 2014/2015 Academic Year. Journal of Education and Practice, 6(30), 94-102.

House, D., \& Raja, M. K. (2019). Phishing : message appraisal and the exploration of fear and self-confidence. Behaviour \& Information Technology, O(0), 1-21. https://doi.org/10.1080/0144929X.2019.1657180

Irani, L. C., \& Laksana, E. P. (2018). Konsep Diri dan Keterbukaan Diri Remaja Broken Home yang Diasuh Nenek. Jurnal Pendidikan: Teori, Penelitian, Dan Pengembangan, 3(5), 685-692.

Jongerden, L., \& Bögels, S. M. (2015). Parenting, Family Functioning and Anxiety-Disordered Children: Comparisons to Controls, Changes After Family Versus Child CBT. Journal of Child and Family Studies, 24(7), 2046-2059. https://doi.org/10.1007/s10826-014-0005-6

Komara, I. B. (2016). Hubungan antara kepercayaan diri dengan prestasi belajar dan perencanaan karir siswa SMP. PSIKOPEDAGOGIA Jurnal Bimbingan Dan Konseling, 5(1), 33. https://doi.org/10.12928/psikopedagogia.v5i1.4474

Oney, E., \& Oksuzoglu-Guven, G. (2015). Confidence: A critical review of the literature and an alternative perspective for general and specific self-confidence. Psychological Reports, 116(1), 149-163. 
Perilaku, M., Ramah, K., Deskriptif, S., Usia, A., Kota, D. A., \& Ganevi, N. (2013). Pelaksanaan program parenting bagi orangtua dalam menumbuhkan perilaku keluarga ramah anak (Studi Deskriptif di Pendidikan Anak Usia Dini Al-Ikhlas Kota Bandung). Jurnal Pendidikan Luar Sekolah, 9(2), 1-11.

Pettersson, C. (2018). Psychological well-being , improved self- confidence, and social capacity : bibliotherapy from a user perspective capacity : bibliotherapy from a user perspective. Journal of Poetry Therapy, O(2), 1-11. https://doi.org/10.1080/08893675.2018.1448955

Reinhardt, E. (1955). Self-Confidence: Can Be Undermined or Developed in School. The Clearing House: A Journal of Educational Strategies, Issues and Ideas, 30(2), 85-87. https://doi.org/10.1080/00098655.1955.11476360

Rezaei, A. (2012). Can self-efficacy and self-confidence explain Iranian female students' academic achievement? Gender and Education, 24(4), 393-409. https://doi.org/10.1080/09540253.2011.630314

Selmi, W., Rebai, H., Chtara, M., Naceur, A., \& Sahli, S. (2018). Self-confidence and affect responses to short-term sprint interval training. Physiology \& Behavior, 188, 42-47.

Siregar, I., \& Asih, E. C. M. (2017). Increasing Self-Confidence of Indonesian Low Ability Student with Green's Motivational Strategies. Journal of Physics: Conference Series, 812(1), 12104. IOP Publishing.

Sofyan, I. (2019). Mindful Parenting: Strategi Membangun Pengasuhan Positif dalam Keluarga. Journal of Early Childhood Care and Education, 1(2), 41-47.

Subadi, T. (2010). Tenaga Kerja Indonesia di Malaysia (Studi Kasus TKW Asal Jawa Tengah dengan Pendekatan Fenomenologi). Forum Geografi, 24(2), 155-172.

Suharto, M. P., \& Nurwati, N. (2018). Peran Extended Family Pada Anak Tkw Yang Terlantar Di Kabupaten Indramayu. Prosiding Penelitian Dan Pengabdian Kepada Masyarakat, 5(2), 165-175.

Sultana, H., \& Fatima, A. (2017). Factors influencing migration of female workers: a case of Bangladesh. IZA Journal of Development and Migration, 7(1), 1-17.

Syamsudin, G. A. (2017). Dampak pola asuh ibu sebagai tenaga kerja wanita (TKW) terhadap kepribadian remaja. Martabat: Jurnal Perempuan Dan Anak, 1(2), 219-244.

Tymes, D. D., Outlaw, K. L., \& Hamilton, B. K. (2016). Life skills interventions to improve social confidence, selfmanagement, and protection against drug use in rural elementary school aged children. Journal of Community Health Nursing, 33(1), 11-19. 